\title{
PROSEDUR TERAPI RADIASI EKSTERNA PADA PASIEN KANKER KANDUNG KEMIH DENGAN METASTASIS ARTICULATIO COXAE
}

\author{
Dwi Sugeng Supriyadi ${ }^{1}$ Dria Wanadi ${ }^{2}$ Himawan Setyono ${ }^{3}$ \\ ${ }^{1,2,3}$ Radiotherapy Department, Regional General Hospital Dr. Moewardi, Indonesia \\ Corresponding author: Dwi Sugeng Supriyadi \\ Email: dwi.ss.radioterapis@gmail.com
}

\begin{abstract}
Background: It has been conducted research about external radiation therapy technique of bladder cancer with articulatio coxae metastasis at Dr. Moewardi Hospital Surakarta in order to explain the procedure of external radiation therapy in bladder cancer with articulatio coxae metastasis and the purpose of asymmetric radiation field that used in external radiation therapy of bladder cancer with articulatio coxae metastasis.

Methods: The type of research conducts is an observational research with case report approach conducted by using direct observation method, interview with radiation oncologist and radiation technologies as well as documenting the data about external radiation therapy of bladder cancer with articulatio coxae metastasis. Results: From the research result, it is obtained the data that external radiation therapy technique of bladder cancer patient with articulatio coxae metastasis is used asymmetric whole pelvic field where right border more wide than left border. The purpose of using asymmetric field is to reach articulatio coxae metastasis in radiation field, to decrease skin dose and time efficiency of radiation therapy.

Conclusions: From a technical point of view, for time efficiency by considering many patients, there is only one plane therapy and the plane can be carried out in an asymmetrical field between the right and left. While the goal from a clinical perspective is to reach the articulatio coxae into the radiation field and reduce the dose received by the skin.
\end{abstract}

Keyword : bladder caqncer; external radiation therapy; articulatio coxae metastasis

\section{Pendahuluan}

Kanker kandung kemih ini merupakan salah satu faktor penyebab dari kematian dan mempunyai angka kejadian yang tinggi, tiap tahun di Inggris 10.000 orang terkena kanker kandung kemih serta hampir setengahnya meninggal. Menurut angka kejadiannya pada laki-laki kanker kandung kemih ini menduduki peringkat keempat dan pada wanita menduduki peringkat kedelapan, serta pada orang kulit putih kanker kandung kemih ini angka kejadiannya lebih tinggi. Kanker kandung kemih mempunyai tingkatan sifat biologi yang luas yaitu dari superficial tumor yang dapat diobati dengan reseksi lokal hingga tumor yang sangat agresif dan infiltratif.

Pengobatan yang dapat dilakukan pada kanker kandung kemih adalah dengan pembedahan, kemoterapi, terapi radiasi dan immunotherapi. Terapi radiasi untuk kanker kandung kemih sebagai modalitas penatalaksanaan tunggal untuk penyakit invasive yang mempunyai kemungkinan sembuh rata-rata $16-30 \%$, ini lebih rendah daripada penatalaksanaan sistektomi, tetapi radiasi dapat digunakan pada klien yang tidak ditangani dengan pembedahan.

Dalam pemberian terapi radiasi eksterna pada kanker kandung kemih dapat dilakukan dengan beberapa teknik yaitu dengan empat lapangan (box techniques), dua lapangan depan dan belakang, teknik rotasi serta teknik tiga lapangan.

Pelaksanaan terapi radiasi eksterna pada kanker kandung kemih di Instalasi Radioterapi RSUD Dr. Moewardi dilakukan dengan teknik terapi radiasi eksterna dengan dua lapangan anterior dan posterior, tetapi pada kasus metastasis pada articulatio coxae lapangan radiasi dibuat tidak simetris dengan salah satu sisi dibuat lebih lebar untuk menjangkau articulatio coxae dan tanpa pemasangan blokade pada area articulatio coxae, kemudian tidak dilanjutkan dengan lapangan booster pada kandung kemih. 
Penelitian ini bertujuan untuk mengetahui prosedur terapi radiasi eksterna pada pasien kanker kandung kemih dengan metastasis articulatio coxae di RSUD Dr. Moewardi Surakarta serta mengetahui tujuan dari penggunaan lapangan penyinaran yang tidak simetris dalam terapi radiasi eksterna pada pasien kanker kandung kemih dengan metastasis articulatio coxae.

\section{Metode}

\section{Observasi}

Melakukan pengamatan langsung pelaksanaan terapi radiasi eksterna pada kanker kandung kemih dengan metastasis articulatio coxae di Instalasi Radioterapi RSUD Dr. Moewardi.

2. Wawancara

Melakukan wawancara mendalam dengan satu orang dokter spesialis onkologi radiasi dan satu orang radiografer radioterapi tentang pelaksanaan terapi radiasi eksterna pada kanker kandung kemih dengan metastasis articulatio coxae di Instalasi radioterapi RSUD Dr. Moewardi.

3. Dokumentasi

Mendokumentasikan catatan medik terapi pasien, hasil foto simulator, data treatment planning system, print out dosimetri dan data penyinaran.

\section{Hasil dan Pembahasan}

Prosedur pelaksanaan terapi radiasi pada pasien kanker kandung kemih dengan metastasis articulatio coxae di RSUD Dr. Moewardi adalah sebagai berikut:

1. Persiapan tindakan terapi radiasi

Penentuan staging kanker dilakukan dengan pemeriksaan klinis pasien dan pemeriksaan penunjang seperti : hasil pemeriksaan histologi (patologi anatomi), foto thorax, USG (ultrasonografi) abdomen, laboratorium darah dan foto pelvis. Penentuan staging ini dibutuhkan untuk perencanaan tindakan terapi radiasi yang akan diberikan juga penentuan volume target radiasi. Sebelum dilakukannya tindakan terapi radiasi pasien juga diberikan penjelasan tentang prosedur terapi radiasi, efek samping yang mungkin akan timbul selama terapi radiasi dan setelahnya, jika pasien telah memahami dan setuju dipersilakan untuk mengisi dan menandatangani inform consent.

2. Simulasi lapangan radiasi
Pesawat simulator yang digunakan dalam simulasi terapi radiasi eksterna pada pasien kanker kandung kemih dengan metastasis articulatio coxae di RSUD Dr. Moewardi dengan merk NPIC type HMD-1B. Simulasi lapangan radiasi yang dilakukan adalah lapangan seluruh panggul dua lapangan depan dan belakang dengan teknik SSD (Source Skin Distance). Dalam simulasi lapangan radiasi diberikan media kontras pada kandung kemih dan batas-batas lapangannya sedikit berbeda dengan lapangan seluruh panggul yang umumnya karena adanya metastasis pada articulatio coxae yang harus masuk dalam lapangan radiasi. Adapun batas-batas lapangan sebagai berikut: (1) batas atas: vertebra lumbal lima; (2) batas bawah: foramen obturatorium; (3) batas lateral kiri: $2 \mathrm{~cm}$ di luar dinding pelvis; (4) batas lateral kanan: $2 \mathrm{~cm}$ dari trokantor mayor.

Untuk perencanaan blok dilakukan pada sisi atas kanan dan kiri lapangan radiasi untuk melindungi sebagian usus halus serta pada sisi kiri bawah guna melindungi kaput femoris kiri.

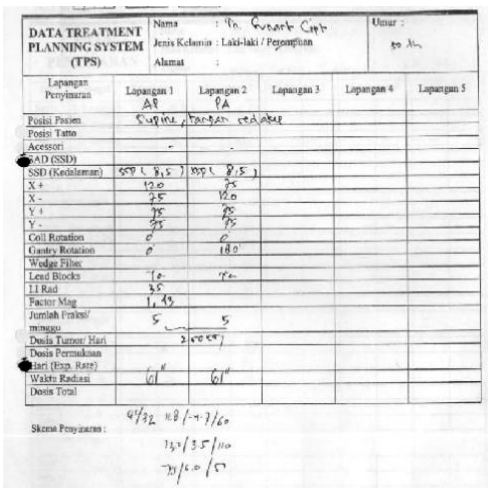

Gambar 1. Data parameter perencanaan radiasi.

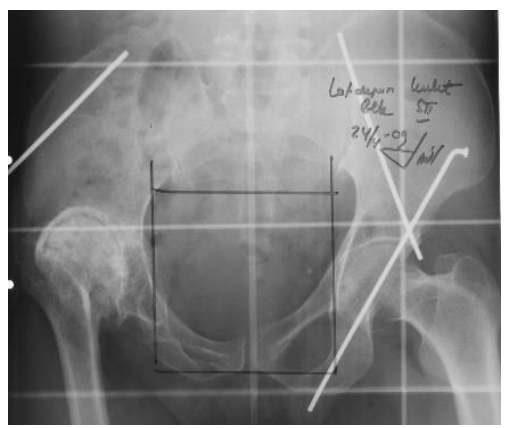

Gambar 2. Foto simulator lapangan radiasi

3. Penghitungan waktu radiasi

Penghitungan waktu radiasi di RSUD Dr. Moewardi dilakukan oleh fisikawan medik dengan menggunakan perangkat komputer TPS 
3D Phoenixplans dari NPIC China. Sehingga waktu penyinaran, kurva isodosis dan perencanaan blok dapat langsung diketahui dari print out komputer tanpa dilakukan secara manual.

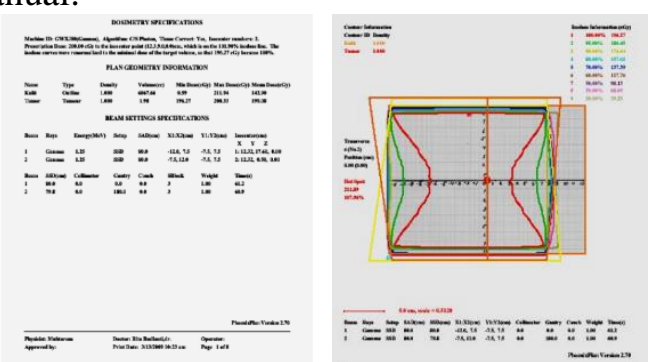

Gambar 3. Printout komputer TPS.

\section{Pelaksanaan tindakan terapi radiasi}

Pelaksanaan terapi radiasi pada pasien kanker kandung kemih dengan metastasis articulatio coxae di RSUD Dr. Moewardi menggunakan pesawat cobalt 60 dengan merk NPIC type GWXJ-80. Pesawat cobalt 60 di RSUD Dr. Moewardi sudah dilengkapi dengan unit komputer kontrol dimana data perencanaan dapat disimpan dalam komputer, sehingga luas lapangan radiasi dan sudut kolimator dapat diatur secara otomatis melalui komputer kontrol serta waktu penyinaran tiap lapangan dapat tersimpan dalam komputer kontrol.

5. Evaluasi dan tindak lanjut

Pada terapi radiasi eksterna pada pasien kanker kandung kemih dengan metastasis articulatio coxae di RSUD Dr. Moewardi evaluasi dilakukan setelah pasien mendapat lima kali radiasi, evaluasi ini berguna untuk melihat efek samping cepat dari radiasi pada tubuh yang terkena radiasi. Dan tindak lanjut setelah selesai radiasi dilakukan setelah enam sampai delapan minggu dengan dilakukan pemeriksaan radiologis ulang dan kontrol dokter spesialis onkologi radiasi untuk melihat efek samping lambat setelah radiasi.

Untuk tujuan dari penggunaan lapangan radiasi tidak simetris untuk terapi radiasi eksterna pada pasien kanker kandung kemih dengan metastasis articulatio coxae di RSUD Dr. Moewardi dilihat dari segi teknis yaitu efisiensi waktu pelaksanaan tindakan terapi radiasi karena tanpa membuat lapangan radiasi khusus untuk metastasisnya, hal ini dilakukan dengan pertimbangan banyaknya pasien dan modalitas terapi radiasi yang hanya satu serta kemampuan dari modalitas yang ada mampu untuk dilakukannya lapangan yang tidak simetris

antara kanan dan kiri. Untuk tujuan dari segi klinis adalah untuk menjangkau articulatio coxae masuk dalam lapangan radiasi, hal ini dengan pertimbangan metastasis adalah target radiasi dan untuk mengurangi dosis yang diterima oleh kulit jika dibandingkan dengan pembuatan lapangan radiasi khusus pada daerah metastasis.

\section{Simpulan}

Pemberian terapi radiasi eksterna pada pasien kanker kandung kemih dengan metastasis articulatio coxae di RSUD Dr. Moewardi dilakukan dengan lapangan seluruh panggul dua lapangan depan dan belakang tanpa dilakukan lapangan booster pada kandung kemih serta dosis total $50 \mathrm{~Gy}$ yang diberikan 2 Gy perhari selama lima fraksi perminggu. Prosedur terapi radiasi eksterna dilakukan dalam beberapa tahap yaitu persiapan tindakan dengan penentuan staging dan volume target radiasi serta penjelasan kepada pasien tentang jalannya terapi radiasi dan kemungkinan efek samping yang akan timbul, simulasi lapangan radiasi dengan pesawat simulator, penghitungan dosis radiasi dengan komputer TPS, pelaksanaan radiasi dengan pesawat cobalt 60 dan dilakukan evaluasi serta tindak lanjut.

Batas-batas lapangan seluruh panggul pada terapi radiasi eksterna pada pasien kanker kandung kemih dengan metastasis articulatio coxae di RSUD Dr. Moewardi adalah vertebra lumbal lima untuk batas atas lapangan, foramen obturatorium untuk batas bawah lapangan, dua centimeter di luar dinding pelvis untuk batas lateral kiri lapangan dan dua centimeter dari trokantor mayor femur kanan untuk batas lateral kanan lapangan.

Tujuan dari penggunaan lapangan tidak simetris untuk terapi radiasi eksterna pada pasien kanker kandung kemih dengan metastasis articulatio coxae di RSUD Dr. Moewardi dari segi teknis adalah untuk efisiensi waktu dengan pertimbangan pasien banyak, pesawat terapi radiasi hanya satu dan pesawat mampu untuk dilakukan lapangan tidak simetris antara kanan dan kiri. Sedangkan tujuan dari segi klinis adalah untuk menjangkau articulatio coxae masuk dalam lapangan radiasi dan mengurangi dosis yang diterima kulit.

\section{Daftar Pustaka}


K. Chao, C. Perez, T. Wang. 2018. Radiation Oncology: Management Decisions. Philadelphia: Lipincott Williams and Wilkins.

A. Barret, S. Morris, J. Dobbs, T. Roques. 2009. Practical Radiotherapy Planning. New York: Oxford University Press Inc.

Faiz dan Moffat. 2005. At a Glance: Anatomi. Jakarta: PT Erlangga.

Grace P A dan Borley N R. 2006. At a Glance: Ilmu Bedah $3^{\text {rd }}$ Edition. Jakarta: PT Erlangga.

Gunderson dan Tepper. 2016. Clinical Radiation Oncology. Philadelphia: Elsevier.

L. Hanna, T. Crosby, F. Macbeth. 2015. Practical Clinical Oncology. New York: Cambridge University Press.

C. Wittekind, H. Asamura, L. Sobin. 2014. TNM Atlas. New Jersey: Wiley-Blackwell.

E. Pearce. 2016. Anatomi dan Fisiologi Untuk Paramedis. Jakarta: PT Gramedia Pustaka Utama.

C. Washington, D. Leaver. 2015. Principles and Practice of Radiation Oncology. Massachusetts: Elsevier Health Science Division.

Susworo R. 2007. Dasar- Dasar Radioterapi. Jakarta: Universitas Indonesia Press.

Taher, A N dan Kotb, M H. 2006. Bone Metastases in Muscle-Invasive Bladder Cancer. Journal of the Egyptian Nat. Cancer Inst. Vol. 18 No. 3. September: 203-208. 